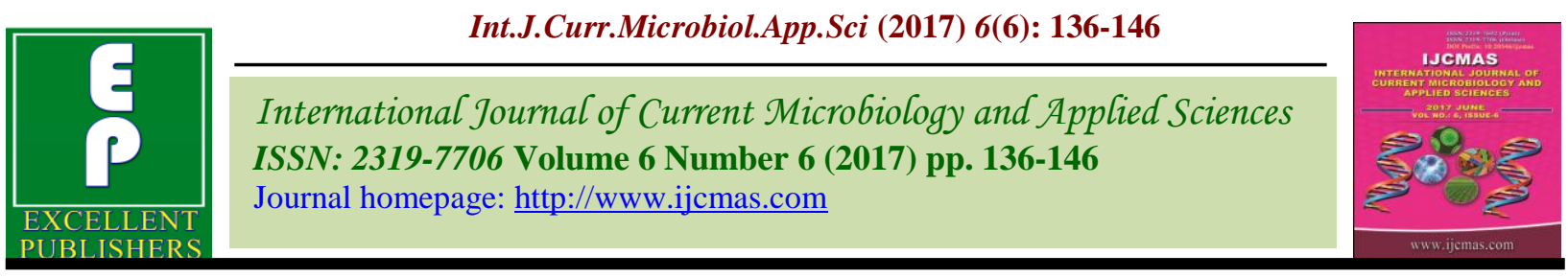

Original Research Article

https://doi.org/10.20546/ijcmas.2017.606.016

\title{
Isolation, Molecular Identification and Antibiotic Resistance of Enterococcus faecalis from Diseased Tilapia
}

\author{
Uma Arumugam*, Nattan Stalin and Gnanadesika Pandian Rebecca \\ Tamil Nadu Fisheries University, State Referral Laboratory for Fish Disease Diagnosis and \\ Aquatic Animal Health, Fisheries Research and Extension Centre, Madhavaram Milk Colony, \\ Chennai-600051, Tamil Nadu, India \\ *Corresponding author
}

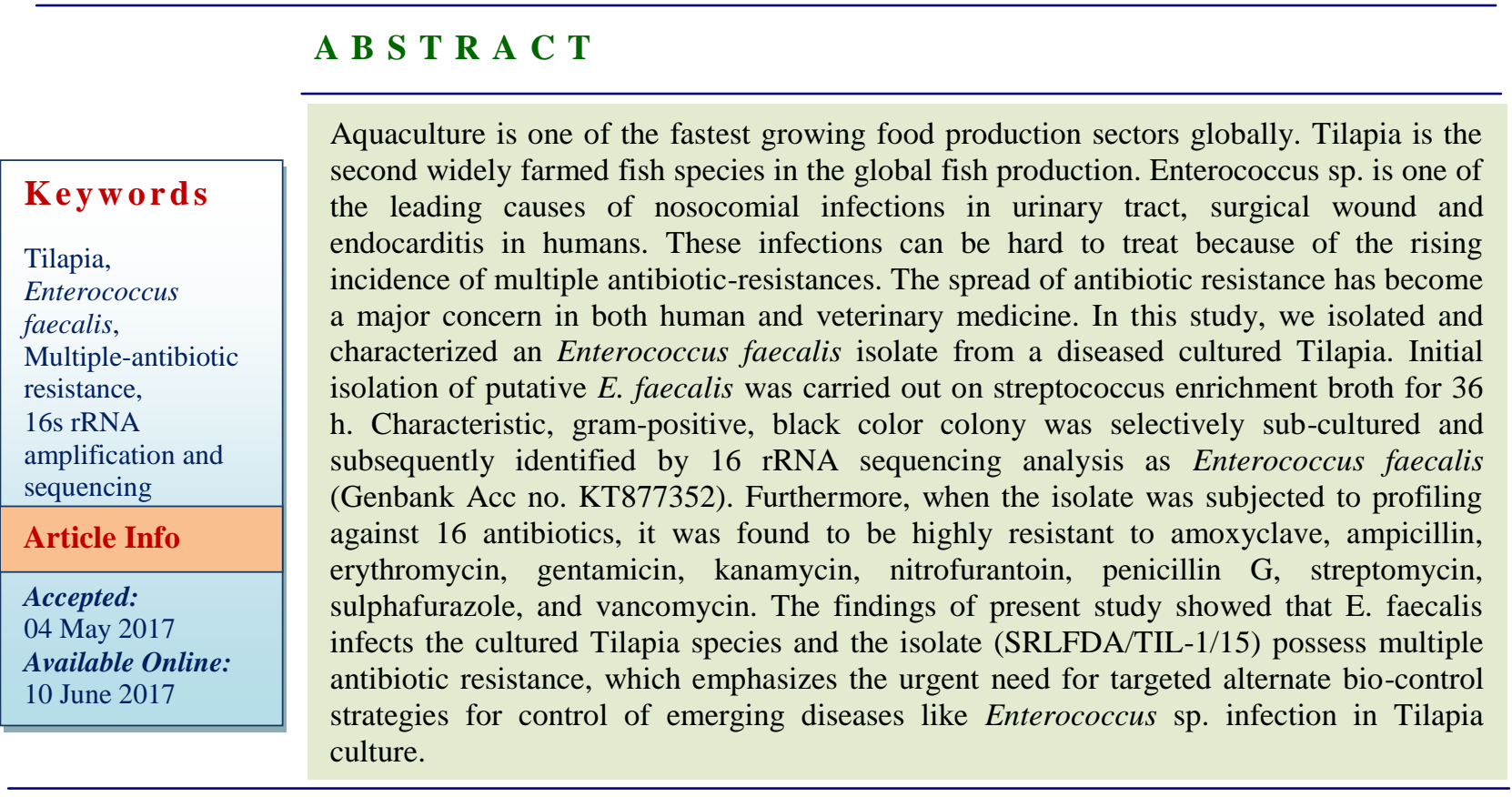

\section{Introduction}

Aquaculture has emerged as one of the important food production sector over recent decades (FAO, 2000). Food fish supply has been reported to increase at the rate of $8.3 \%$ annually (FAO, 2014). Tilapia is the second most farmed fish species in the world with the estimated global production of around 5.5 million metric tons (mmt) in 2016, but is predicted to increase by $4.5 \%$ in 2017 reaching $5.8 \mathrm{mmt}$ (RGCA, 2016). Tilapia may play an important role in the growth of aquaculture and continue to contribute in the future food demand in developing and developed countries.

As in any other fish culture operations, disease is the major factor that adversely affects the production of farmed Tilapia. Although, Tilapia is considered hardy with high disease resistance, bacterial diseases caused due to Streptococcus sp (Atyah et al., 2010; Chen et al., 2015; Li et al., 2015; Shen et al., 2016) and Enterococcus sp (Martins et al., 2009) have been reported. Enterococcus 
sp. is a commensal gram-positive, diplococcal bacterium which are dominant in fish, shellfish, and other aquatic animals (Wilson and McAfee, 2002; Sonsa Ard et al., 2015; Chajecka-Wierzchowsk et al., 2016; Paganelli et al., 2017). Nonetheless, Enterococcus sp. in contaminated food fishes can lead to lifethreatening illness in human such as endocarditis (Dahl and Bruun, 2013), bacteremia (Stuart et al., 2006), urinary tract infection and meningitis (Tebruegge et al., 2011) and its resistance to antibiotics is emerging as a major problem in treating these infections (Koch et al., 2004). In addition, the ubiquity of Enterococcus sp in food has been reported to be mainly a result of their resistance to unfavorable environmental conditions during production technology with food fish storage conditions and their adaptability (Sarra et al., 2013). Because of their relative abundance and their resistance to environmental factors, Enterococcus $\mathrm{sp}$ have been proposed as an indicator bacteria for hygiene quality, as well as for antimicrobial resistance in food and water (Boehm and Sassoubre, 2014). Enterococcus sp. has emerged as important healthcare associated pathogen (Arias and Murray, 2012; Khan et al., 2015), as they are intrinsically resistant and tolerant to numerous commercial antibiotics and are able to acquire drug resistance either by chromosome, transfer of plasmid or transposing acquisition containing genetic sequences that confer resistance in other bacteria (Eaton and Gasson, 2001; Ben Belgacem et al., 2010; Hammerum Lester and Heuer, 2010). In the last decade, several virulence factors have been described in Enterococci including cytolysins (Vankerckhoven et al., 2004), gelatinase (Mannu et al., 2003), serine protease (Mohamed et al. 2004), hyaluronidase, aggregation substance (Muscholl-silberhorn et al., 2000) and extracellular surface protein (Shankar et al., 1999). The cell wall adhesion and biofilm formation properties of
Enterococcus sp. have also been described (Barbosa, Gibbs and Teixeira, 2010).

The presence of commensal microbiota in environmental ecosystems (Salyers and Shoemakers, 2006), human ecosystems and in food suggest that microorganisms can play a essential role in transfer of antibiotic resistant genes and the food chain may play a key role in the transmission of resistance between the environment and human (Marshall and Levy, 2009). Although, the detection of virulence factors may indicate a virulence potential in food isolates, food-borne Enterococcal infection have never been reported (Giraffa, 2002; Foulquie-Moreno et al., 2006; Valenzuela et al., 2010). However, the consumption of food carrying antibioticresistant bacterial populations is considered a possible transfer route (Kruse and Sorum, 1994). In recent years, growing interest in the consumption of fish foods, which are considered balanced healthy foods have been observed. In the present study E. faecalis was isolated from a diseased Tilapia, identified by $16 \mathrm{~S}$ rRNA amplification and sequencing and its antibiotics resistance was studied.

\section{Materials and Methods}

\section{Samples}

Diseased Tilapia sample (Average weight 57 $\mathrm{g}$, average $18 \mathrm{~cm}$ ) was collected from a fresh water aquaculture farm in Chennai, Tamilnadu, India. At site, behavioral abnormalities, gross and clinical sign of the diseased Tilapia were recorded (Heil, 2009). Morbid tilapia fish with typical disease symptom was first rinsed in sterile saline and dissected aseptically. Inoculum from the kidney of tilapia was collected aseptically and was spread plated onto brain heart infusion agar (BHIA) and Streptococcus selective isolation broth (SIB) supplemented with $6.5 \%$ $\mathrm{NaCl}$. Presumptive single (black; 1mm dia) 
colony on bile-esculin agar (Himedia, India) were streaked on to Streptococcus selective isolation agar (SIA) (Himedia, India) plates for further purification at $30 \pm 2^{\circ} \mathrm{C}$ for $24-36 \mathrm{~h}$ and maintained on BHIA slants at room temperature $\left(28 \pm 2^{\circ} \mathrm{C}\right)$.

\section{Phenotypic characterization}

A series of biochemical tests were performed to identify the isolate up to genus level (Svec and Devriese, 2015). Biochemical characterization like, gram strain, catalase test, and growth at $6.5 \% \mathrm{NaCl} / 45^{\circ} \mathrm{C}$, was done using Rapid HiStrepTM biochemical test kit specific for Streptococcus sp. (HiMedia, India). The phenotypic characteristics documented in earlier reports (Murray, 1990; Teixeira et al., 2011) were compared for presumptive identification of the isolate.

\section{Antibiotics susceptibility test}

The antimicrobial susceptibility of the isolate was determined by disc diffusion technique using Muller-Hinton's agar (Bauer et al., 1966). The isolate was tested against 16 antibiotics (Himedia, India) viz., amoxyclave (AMC), ampicillin (AMP), chloramphenicol (C), ciprofloxacin (CIP), clindamycin (CO), co-trimoxazole (COT), erythromycin (E), gentamicin (GEN), kanamycin (K), nitrofurantoid (NIT), norfloxacin (NX), oxytetracycline $(\mathrm{O})$, penicillin-G $(\mathrm{P})$, streptomycin (S), sulphafurazole (SF), and vancomycin (VA). The isolate (Himedia, India) was grown overnight (OD 2 at 600nm) in tryptic soy agar and spreaded on MullerHinton's agar. After $30 \mathrm{~min}$, four dissimilar antibiotics discs were positioned on the plates and incubated for $10-24 \mathrm{~h}$ at $37^{\circ} \mathrm{C}$. After incubation, the zone of inhibition (by mean of diameter in $\mathrm{mm}$ ) was measured around the discs and compared with the interpretive chart (Clinical and Laboratory Standards Institute,
CLSI guidelines, 2012).

\section{Molecular identification}

\section{DNA extraction}

The genomic DNA was extracted from the Enterococcus sp isolate (SRLFDA/TIL-1/15) using QIAamp genomic DNA kit (Qiagen, Germany) as per manufacturer's protocol.

\section{S rRNA gene amplification and sequence analysis}

The $16 \mathrm{~S}$ ribosomal RNA gene (16S rRNA) of the isolate was amplified using a set of universal prokaryotic primers $8 \mathrm{~F}, 5^{\prime}$ AGAGTTTGATCCTGGCTCAG-3' and 1492R， 5'-GGTTACCTTGTTACGACTT-3' (Eden et al., 1991). The PCR amplification was performed in a $50 \mu 1$ reaction volume with $25 \mu 1$ of PCR master mix (Ampliqon, Denmark), $2.0 \mu$ l each of forward and reverse primers, and $2.0 \mu \mathrm{l}$ (100 ng) of genomic DNA template and $(19 \mu \mathrm{l})$ nuclease-free water. The PCR reaction was carried out in T-100 TM thermal cycler (Bio-Rad, USA). Amplification was done by initial denaturation at $95{ }^{\circ} \mathrm{C}$ for $5 \mathrm{~min}$, followed by 30 cycles of denaturation at $94{ }^{\circ} \mathrm{C}$ for $30 \mathrm{~s}$, annealing at $55{ }^{\circ} \mathrm{C}$ for $30 \mathrm{~s}$ and extension at $72{ }^{\circ} \mathrm{C}$ for $60 \mathrm{~s}$ with a final extension at $72{ }^{\circ} \mathrm{C}$ for $5 \mathrm{~min}$. The PCR product was resolved on a $1.5 \%$ agarose gel containing $0.5 \mu \mathrm{g} / \mathrm{mL}$ ethidium bromide in $1 \mathrm{X}$ Tris-Borate-EDTA (TBE) buffer and electrophoresed at $100 \mathrm{~V}$.

\section{Sequencing analysis}

The amplified 16S rRNA gene PCR product was purified using HiyieldTM Gel/PCR DNA mini kit (real genomic, Taiwan) as per the manufacturer's instructions. Nucleotide sequencing (forward and reverse) was done with a commercial sequencing service (Eurofins, India). The forward and reverse 
sequences were assembled by DNA baser sequence assembler v3.5.3 (2012) to form consensus sequence and identified by NCBI BLAST (http://blast.ncbi.nlm.nih.gov/Blast. cgi) search algorithm.

\section{PCR detection of tetracycline resistance genes}

The isolate SRLFDA/TIL-1/15 was examined for the presence of the tetracycline resistance encoding genes viz., tet (K) tet (L), following the primers and protocols of the previous researchers (Aarestrup et al., 2000; Garofalo et al., 2007; Ullah et al., 2012).

\section{Results and Discussion}

Isolation and identification of $E$. faecalis, SRLFDA/TIL-1/15

The clinical symptoms recorded in the Tilapia sample were lethargy, abdominal ascites, organ discoloration, necrosis of the spleen and haemorrhages in kidney. The isolate recovered from kidney samples yielded a predominant black colony on bile-esculin agar (BEA) and Streptococcus selective isolation (SIA) agar. Microscopic observation of the stained smear revealed Gram-positive cocci arranged in diplococci or short chain and displayed oxidase and catalase negative activity. The isolate could be grown at above $45{ }^{\circ} \mathrm{C}$ on BHI medium containing $6.5 \%$ $\mathrm{NaCl}$, at $\mathrm{pH}$ 7.5. Biochemical characterization of the isolate (MLTEC) as assessed by Rapid HiStrepTM biochemical test is presented in table 1.

Enterococci are one of the most common group of bacteria present in foods (Paganelli et al., 2017), mainly due to their resistance to adverse environmental conditions during production technology, as well as food storage conditions and their high adaptability (Boehm and Sassoubre, 2014). Enterococci bacterial contamination in seafood products have been documented (Wilson and McAfee, 2002; Sonsa-Ard et al., 2015).

\section{Molecular confirmation by $16 \mathrm{~S}$ rRNA}

PCR amplification of the $16 \mathrm{~S}$ rRNA of the isolate (SRLFDA/TIL-1/15) resulted in an amplified product of 1450 bp size (Fig. 1). On the basis of gene sequence similarity carried out by BLAST NCBI, the isolate was identified as E. faecalis (Genbank Acc. No. KT877352) with 99-100 \% homology with other E. faecalis strains in the GenBank database (NCBI).

$16 \mathrm{~S}$ ribosomal RNA present in bacteria plays a major role in gene coding due to the highly conserved region. It is considered as a standard marker for bacterial phylogenetic analysis to differentiate the species (Nagpal et al., 1998). Recent studies demonstrated that the different Enterococcus strains isolated from diverse sea water environment elucidated unique nucleotide position and evolution of Enterococcus and its related species Chajęcka -Wierzchowska et al., 2016; Prichula et al. 2016). Moreover, many recent reports have been published on the $16 \mathrm{~S}$ rRNA sequences of Enterococcus $\mathrm{sp}$ and the phylogenetic relationship deduced from analysis of these sequences (Deasy et al., 2000; Mannu et al., 2003; Ben Belgacem et al., 2010; Galimand et al., 2011; GallowayPena et al., 2012).

\section{Antibiotic susceptibility profile}

Antibiotic sensitivity test showed that the $E$. faecalis (SRLFDA/TIL-1/15) was either resistant and/or intermediately resistant to more than nine classes of antibiotic groups (Table 2). The isolate showed resistance to amoxyclave (AMC), ampicillin (AMP), erythromycin (E), gentamicin (GEN), kanamycin (K), nitrofurantoin (NIT), 
oxytetracycline (O), penicillin-G (P), streptomycin (S), and sulphafurazole (SF) and was intermediately resistant to chloramphenicol (C), ciprofloxacin (CIP), clindamycin $(\mathrm{CO})$, norfloxacin $(\mathrm{NX})$, and vancomycin (VA). The isolate was observed to be susceptible only to co-trimoxazole (COT), (Table 2). PCR amplification of the tet (tet $\mathrm{K}$ and tet $\mathrm{L}$ ) genes showed that the $E$. faecalis isolate (SRLFDA/TIL-1/15) from Tilapia carry tet K (360 bp) and tet L (1077 bp) genes (Fig. 2).

Table.1 Biochemical characterization of Enterococcus faecalis strain (SRLFDA/TIL-1/15) isolated from diseased Tilapia

\begin{tabular}{lc}
\hline Biochemical tests & $\begin{array}{c}\text { Enterococcus faecalis } \\
\text { SRLFDA/TIL-1/15 }\end{array}$ \\
\hline Gram reaction & + \\
Voges-Proskauer's & + \\
Bile-Esculin agar (black) & + \\
Esculin hydrolysis & + \\
PYR & + \\
ONPG & - \\
Arginine utilization & nd \\
Glucose & + \\
Lactose & + \\
Arabinose & - \\
Sorbitol & + \\
Sucrose & + \\
Mannitol & + \\
Raffinose & + \\
Salt tolerance $(6.5 \%$ & - \\
NaCl $)$ & + \\
\hline
\end{tabular}

Fig.1 PCR amplification of 16S rRNA of E. faecalis isolate from Tilapia

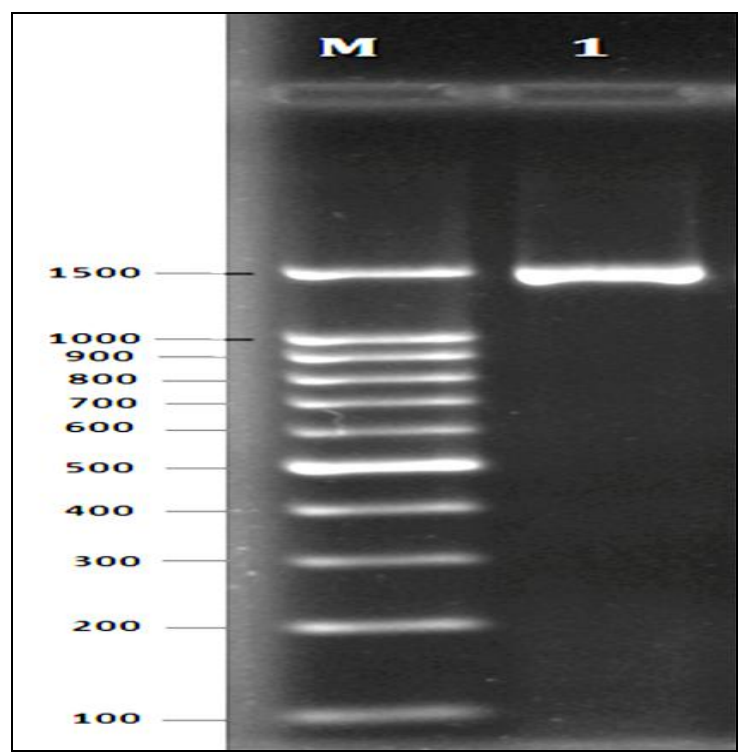


Table.2 Antibiotic resistance profile of Enterococcus faecalis strain (SRLFDA/TIL-1/15) isolated from diseased Tilapia

\begin{tabular}{clc}
\hline S. No & \multicolumn{1}{c}{ Antibiotics } & TE \\
\hline 1 & Amoxyclave (AMC) & $0(\mathrm{R})$ \\
2 & Ampicillin (AMP) & $7(\mathrm{R})$ \\
3 & Chloramphenicol (C) & $17(1)$ \\
4 & Ciprofloxacin (CIP) & $18(1)$ \\
5 & Co-Clindamycin (CO) & $12(1)$ \\
6 & Co-Trimoxazole (COT) & $20(\mathrm{~S})$ \\
7 & Erythromycin (E) & $9(\mathrm{R})$ \\
8 & Gentamicin (GEN) & $7(\mathrm{R})$ \\
9 & Kanamycin (K) & $0(\mathrm{R})$ \\
13 & Nitrofurantoin (NIT) & $12(\mathrm{R})$ \\
10 & Norfloxacin (NX) & $16(1)$ \\
11 & Oxytetracycline (O) & $0(\mathrm{R})$ \\
12 & Penicillin-G (P) & $17(\mathrm{R})$ \\
14 & Streptomycin (S) & $0(\mathrm{R})$ \\
15 & Sulphafurazole (SF) & $11(\mathrm{R})$ \\
16 & Vancomycin (VA) & $16(1)$ \\
& Ratio S: I: R & $\mathbf{1 : 5 : ~ 1 0}$ \\
\hline
\end{tabular}

Zone of inhibition measured (mm) S=sensitive, I=intermediate, $\mathrm{R}=$ resistant, amoxyclav $(30 \mu \mathrm{g})$, Ampicillin (10 $\mu \mathrm{g})$, Penicillin-G (10 units), streptomycin $(10 \mu \mathrm{g})$, kanamycin $(30 \mu \mathrm{g})$, vancomycin $(30 \mu \mathrm{g})$, erythromycin $(15 \mu \mathrm{g})$, clindamycin $(2 \mu \mathrm{g})$, norfloxacin $(10 \mu \mathrm{g})$, ciprofloxacin $(5 \mu \mathrm{g})$, chloramphenicol $(30 \mu \mathrm{g})$, co-trimoxazole $(25 \mu \mathrm{g})$, gentamicin $(10 \mu \mathrm{g})$, nitrofurantoin $(300 \mu \mathrm{g})$, oxytetracycline $(30 \mu \mathrm{g})$ and sulphafurazole $(300 \mu \mathrm{g})$.

Fig.2 PCR amplified fragments of the tetracycline resistance genes in E. faecalis isolated from diseased Tilapia. Lane M- 100 bp DNA ladder;

Lane 1, tet $\mathrm{K}$ gene (360 bp); lane 2, tet L gene (1077 bp)

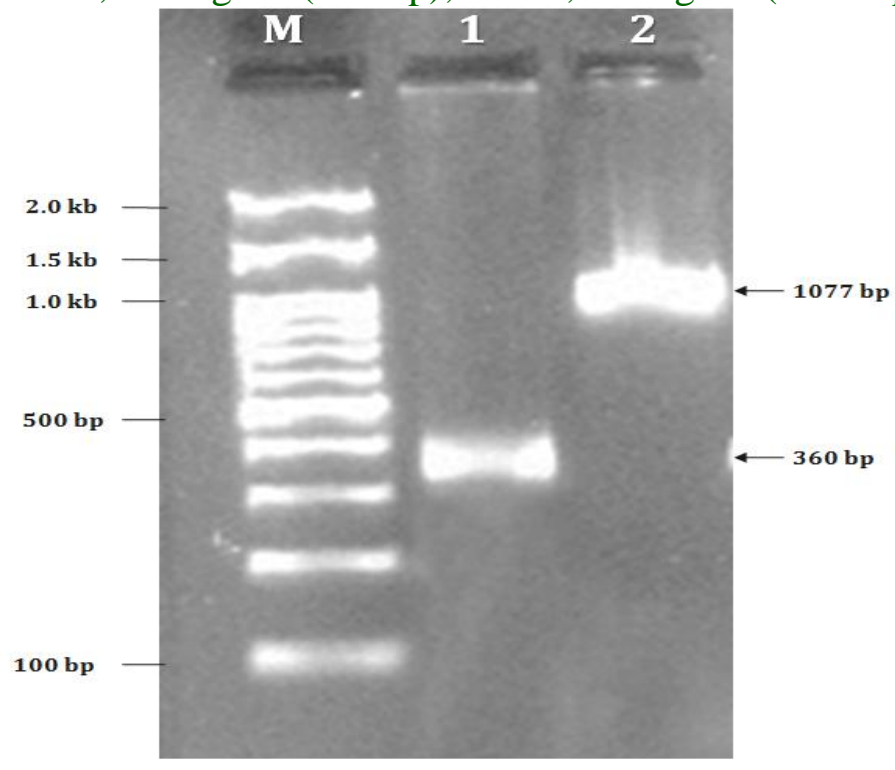

E. faecalis isolate (SRLFDA/TIL-1/15) was resistant to drugs frequently used to treat bacterial infections in humans and veterinary medicine, including erythromycin, ciprofloxacin, norfloxacin and vancomycin (Bates et al., 1994; Prichula et al., 2016). 
Antibiotics represent one of the most prominent aquatic pollutants (Tello et al., 2012). The presence of antibiotics in water can cause serious environmental issues, such as the emergence of resistance due to selective pressure (Baquero et al., 2008). Recently, several studies have reported the development of multiple antibiotic resistance in the microbes of the aquaculture systems (Stalin and Srinivasan, 2016; Prichula et al., 2016; Uma and Ronald, 2016). Although, most of the studies on antibiotic resistance and virulence of Enterococci sp have been carried out in strain isolated from clinical samples, recent reports have suggested that environment and food could play a significant role in the transmission of resistance to humans (Gomes et al., 2008; Koluman, 2009; Barbosa et al., 2010; Chajęcka Wierzchowska et al., 2016). The E. faecalis isolate (SRLFDA/TIL-1/15) was found to be resistant to $62 \%$ of the antibiotics tested in this study with multiple resistances to ten different antibiotics. Resistances to upto eight antibiotics have been reported in isolates from other aquaculture sources (Akinbowale et al., 2006). The amplification of (tet $\mathrm{K}$ and tet $\mathrm{L}$ ) resistant genes and the tetracycline resistance of the E. faecalis isolate (SRLFDA/TIL-1/15) in the antibiotics sensitivity test showed that the resistance shown against tetracycline could be due to the expression of these genes. tet genes are reported to be widely disseminated in the environment (Pallecchi et al., 2008; Di Cesare et al., 2012). The identification of tetracycline resistance determinants may be used as additional genotypic markers for the purpose of outbreak investigation and evolution of gene exchange (Koike et al., 2007; Ng et al., 2001; Ullah et al., 2012; Rico et al., 2014; Prichula et al., 2016).

In conclusion, this is the first report from India on the isolation and confirmation of $E$. faecalis from diseased Tilapia. The presence of antibiotic resistant genes, tet $\mathrm{K}$ and tet $\mathrm{L}$ shows that there is a need for judicious use of antibiotics in aquaculture and to adopt alternate and safe measures for the management of disease in aquaculture.

\section{Acknowledgments}

We are thankful to the National Agriculture Development Programme (NADP), (Grant No.30/FREC-NADP 2016-17) for financial support.

\section{References}

Aarestrup, F.M., Agerso, Y. Gerner-Smidt, P. Madsen, M. Jensen, L.B. 2000. Comparison of antimicrobial resistance phenotypes and resistance genes in Enterococcus faecalis and Enterococcus faecium from humans in the community, broilers, and pigs in Denmark. Diagn. Microbiol. Infect. Dis., 37, 127-137.

Akinbowale, O.L., Peng, H. Barton, M.D. 2006. Antimicrobial resistance in bacteria isolated from aquaculture sources in Australia. J Appl Microbiol., 100, 1103-1113.

Arias, C.A., and Murray, B.E. 2012. The rise of the Enterococcus: beyond vancomycin resistance. Nat. Rev. Microbiol., 10, 266-78.

Atyah, M.A.S., Zamri-Saad, M. Siti-Zahrah, A. 2010. First report of methicillinresistant Staphylococcus aureus from cage-cultured tilapia (Oreochromis niloticus). Vet. Microbiol., 144, 502504.

Barbosa, J., Gibbs, P.A. Teixeira, P. 2010. Virulence factors among Enterococci isolated from traditional fermented meat products produced in the North of Portugal. Food Control, 21, 651-656.

Bates, J., Jordens, J. Griffith, D.T. 1994. Farm animals as putative reservoir for 
vancomycin resistant enterococcal infections in man. J. Antimicrob. Chemother, 34, 507-516.

Bauer, A.W., Kirby, W.M.M, Sherris, J.C, Turck, M. 1966. Antibiotic susceptibility testing by a standardized single disk method. Am J Clin Pathol., 45(4):493-6?

Ben Belgacem, Z., Ben, Abriouel, H. Omar, N. Ben, Lucas, R. Martínez-Canamero, M. Gálvez, A. Manai, M. 2010. Antimicrobial activity, safety aspects, and some technological properties of bacteriocinogenic Enterococcus faecium from artisanal Tunisian fermented meat. Food Control, 21, 462-470.

Boehm, A.B., Sassoubre, L.M. 2014. Enterococci as Indicators of Environmental Fecal Contamination. 2014 Feb 5. In: Gilmore, M.S., Clewell, D.B, Ike Y, et al., editors. Enterococci: From Commensals to Leading Causes of Drug Resistant Infection. Boston: Massachusetts Eye and Ear Infirmary; 2014-. Available from: https://www.ncbi.nlm.nih.gov/books/N BK190421/

Chajęcka-Wierzchowska, W., Zadernowska, A. Łaniewska-Trokenheim, Ł. 2016. Virulence factors, antimicrobial resistance and biofilm formation in Enterococcus spp. isolated from retail shrimps. LWT - Food Sci. Technol., 69, 117-122.

Chen, M., Wang, R. Luo, F.G. Huang, Y. Liang, W.W. Huang, T. Lei, A.Y. Gan, X. Li, L.P. 2015. Streptococcus agalactiae isolates of serotypes Ia, III and $\mathrm{V}$ from human and cow are able to infect tilapia. Vet. Microbiol, 180, 129135

CLSI, 2012. Performance standards for antimicrobial susceptibility testing; Twenty-Second Informational Supplement. Clinical and Laboratory Standards Institute, Wayne, PA 19087,
USA, CLSI document M100-S22, Vol. 32(3).

Dahl, A., and Bruun, N.E. 2013. Enterococcus faecalis infective endocarditis: focus on clinical aspects. Expert Rev. Cardiovasc. Ther, 11, 1247-57.

Deasy, B.M., Rea, M.C. Fitzgerald, G.F. Cogan, T.M. Beresford, T.P. 2000. A Rapid PCR Based Method to Distinguish between Lactococcus and Enterococcus. Syst. Appl. Microbiol., 23, 510-522.

Di Cesare, A., Vignaroli, C. Luna, G.M. Pasquaroli, S. Biavasco, F. 2012. Antibiotic-Resistant Enterococci in Seawater and Sediments from a Coastal Fish Farm. Microb. Drug Resist, 18, 502-509.

Eaton, T.J., and Gasson, M.J. 2001. Molecular screening of Enterococcus virulence determinants and potential for genetic exchange between food and medical isolates. Appl. Environ. Microbiol, 67, 1628-1635.

Eden, P.A., Schmidt, T.M. Blakemore, R.P. Pace, N.R. 1991. Phylogenetic analysis of Aquaspirillum magnetotacticum using polymerase chain reactionamplified 16S rRNA-specific DNA. Int. J. Syst. Bacteriol., 41, p. 324-325.

FAO, 2014. The state of world fisheries and aquaculture. FAO Rome, Italy.

Food Agriculture Organization of the United Nations, 2000.The State of World Fisheries and Aquaculture - 2000. Available at: http://www.fao.org/.

Foulquié Moreno, M.R., Sarantinopoulos, P. Tsakalidou, E. De Vuyst, L. 2006. The role and application of Enterococci in food and health. Int. J. Food Microbiol, $106,1-24$.

Galimand, M., Schmitt, E. Panvert, M. Desmolaize, B. Douthwaite, S. Mechulam, Y. Courvalin, P. 2011. Intrinsic resistance to aminoglycosides 
in Enterococcus faecium is conferred by the 16S rRNA m5C1404-specific methyltransferase EfmM. RNA., 17, 251-62.

Galloway-Peña, J.R., Rice, L.B. Murray, B.E. 2011. Analysis of PBP5 of early U.S. isolates of Enterococcus faecium: Sequence variation alone does not explain increasing ampicillin resistance over time. Antimicrob. Agents Chemother., 55, 3272-3277.

Garofalo, C., Vignaroli, C. Zandri, G. Aquilanti, L. Bordoni, D. Osimani, A. Clementi, F. Biavasco, F. 2007. Direct detection of antibiotic resistance genes in specimens of chicken and pork meat. Int. J. Food Microbiol, 113, 75-83.

Giraffa, G., 2002. Enterococci from foods. FEMS Microbiol. Rev., 26, 163-171.

Gomes, B.C., Esteves, C.T. Palazzo, I.C. V, Darini, A.L.C. Felis, G.E. Sechi, L.A. Franco, B.D.G.M. De Martinis, E.C.P. 2008. Prevalence and characterization of Enterococcus spp. isolated from Brazilian foods. Food Microbiol, 25, 668-675.

Hammerum, A.M., Lester, C.H. Heuer, O.E. 2010. Antimicrobial-resistant Enterococci in animals and meat: a human health hazard. Foodborne Pathog. Dis., 7, 1137-1146.

Heil, N., 2009. National wild fish health survey. Laboratory procedures manual, 5th edn. U.S. Fish and Wildlife Service, warm springs, GA. p. 409.

Khan, H.A., Ahmad, A. Mehboob, R. 2015. Nosocomial infections and their control strategies. Asian Pac. J. Trop. Biomed., 5, 509-514.

Koch, S., Hufnagel, M. Theilacker, C. Huebner, J. 2004. Enterococcal infections: Host response, therapeutic, and prophylactic possibilities. Vaccine, 22, 822-830.

Koike, S., Krapac, I.G. Oliver, H.D. Yannarell, A.C. Chee-Sanford, J.C.
Aminov, R.I. Mackie, R.I. 2007. Monitoring and source tracking of tetracycline resistance genes in lagoons and groundwater adjacent to swine production facilities over a 3-year period. Appl. Environ. Microbiol, 73, 4813-4823.

Koluman, A., Akan, L.S. Çakiro-lu, F.P. 2009. Occurrence and antimicrobial resistance of Enterococci in retail foods. Food Control, 20, 281-283.

Kruse, H., and Sørum, H., 1994. Transfer of multiple drug resistance plasmids between bacteria of diverse origins in natural microenvironments. Appl. Environ. Microbiol., 60, 4015-21.

Li, L.P., Wang, R. Liang, W.W. Huang, T. Huang, Y. Luo, F.G. Lei, A.Y. Chen, M. Gan, X. 2015. Development of live attenuated Streptococcus agalactiae vaccine for tilapia via continuous passage in vitro. Fish Shellfish Immunol, 45, 955-963.

Mannu, L., Paba, A. Daga, E. Comunian, R. Zanetti, S. Duprè, I. Sechi, L.A. 2003. Comparison of the incidence of virulence determinants and antibiotic resistance between Enterococcus faecium strains of dairy, animal and clinical origin. Int. J. Food Microbiol, 88, 291-304.

Marshall, B.M., Ochieng, D.J. Levy, S.B. 2009. Commensals: Underappreciated Reservoir of Antibiotic Resistance. Microbe, 4, 231-238.

Mohamed, J.A., Huang, W. Nallapareddy, S.R. Teng, F. Murray, B.E. 2004. Influence of Origin of Isolates, Especially Endocarditis Isolates, and Various Genes on Biofilm Formation by Enterococcus faecalis. Infect. Immun. 72, 3658-3663.

Murray, B.E., 1990. The life and times of the Enterococcus. Clin. Microbiol. Rev., 3, 46-65. 
Muscholl-silberhorn, A., Wirth, R. Susa, M. Marre, R. Rozdzinski, E.V.A. 2000. Aggregation substance promotes adherence, phagocytosis, and intracellular survival of Enterococcus faecalis within human macrophages and suppresses respiratory burst. Infect Immun., 68, 4900-4906.

Nagpal, M.L., Fox, K.F. Fox, A. 1998. Utility of $16 \mathrm{~S}-23 \mathrm{~S}$ rRNA spacer region methodology: how similar are interspace regions within a genome and between strains for closely related organisms? J. Microbiol. Methods., 33, 211-219.

Ng, L.K., Martin, I. Alfa, M. Mulvey, M. 2001. Multiplex PCR for the detection of tetracycline resistant genes. Mol. Cell. Probes., 15, 209-215.

Paganelli, F.L., van de Kamer, T., Brouwer, E.C., Leavis, H.L., Woodford, N., Bonten, M.J.M., Willems, R.J.L., Hendrickx, A.P.A., 2017. Lipoteichoic acid synthesis inhibition in combination with antibiotics abrogates growth of multidrug-resistant Enterococcus faecium. Int. J. Antimicrob. Agents, 49, 355-363.

Pallecchi, L., Bartoloni, A. Paradisi, F. Rossolini, G.M. 2008. Antibiotic resistance in the absence of antimicrobial use: mechanisms and implications. Expert Rev. Anti. Infect. Ther., 6, 725-732.

Prichula, J., Pereira, R.I. Wachholz, G.R. Cardoso, L.A. Tolfo, N.C.C. Santestevan, N.A. Medeiros, A.W. Tavares, M. Frazzon, J. D'Azevedo, P.A. Frazzon, A.P.G. 2016. Resistance to antimicrobial agents among Enterococci isolated from fecal samples of wild marine species in the southern coast of Brazil. Mar. Pollut. Bull., 105, $51-57$.

RGCA, 2016. Global Farmed Finfish Production Outlook: Slower-paced growth November 4, 2016 by Ragnar Tveteras. http://advocate.gaalliance.org/ global-farmed-finfish-production-out look-slower-pacedgrowth/\#sthash.NvVHd6mE.dpuf

Rico, A., Oliveira, R. McDonough, S. Matser, A. Khatikarn, J. Satapornvanit, K. Nogueira, A.J.A. Soares, A.M.V.M. Domingues, I. Van Den Brink, P.J. 2014. Use, fate and ecological risks of antibiotics applied in tilapia cage farming in Thailand. Environ. Pollut, $191,8-16$.

Salyers, A. Shoemaker, N.B. 2006. Reservoirs of antibiotic resistance genes. Anim. Biotechnol., 17, 137-146.

Sarra, M., Taoufik, G. Patrick, L.C. Benjamin, B. Yannick, F. Khaled, H. 2013. Isolation and Characterization of Enterococci Bacteriocinic Strains from Tunisian Fish Viscera. Food Nutr. Sci., 4, 701-708.

Shankar, V., Baghdayan, A.S. Huycke, M.M. Lindahl, G. Gilmore, M.S. 1999. Infection-derived Enterococcus faecalis strains are enriched in esp, a gene encoding a novel surface protein. Infect. Immun., 67, 193-200.

Shen, Y., Ma, K. Liu, F. Yue, G.H. 2016. Characterization of two novel gadd45a genes in hybrid tilapia and their responses to the infection of Streptococcus agalactiae. Fish Shellfish Immunol, 54, 276-281.

Sonsa-Ard, N., Rodtong, S. Chikindas, M.L. Yongsawatdigul, J. 2015. Characterization of bacteriocin produced by Enterococcus faecium $\mathrm{CN}$ 25 isolated from traditionally Thai fermented fish roe. Food Control, 54, 308-316.

Stalin, N. and Srinivasan, P. 2016. Molecular characterization of antibiotic resistant Vibrio harveyi isolated from shrimp aquaculture environment in the south 
east coast of India. Microb. Pathog., 97, $110-118$.

Stuart, C.H., Schwartz, S.A. Beeson, T.J. Owatz, C.B. 2006. Enterococcus faecalis: Its role in root canal treatment failure and current concepts in retreatment. J. Endod., 32, 93-98.

Svec, P., and Devriese, L. A. 2015. Enterococcus. Bergey's Manual of Systematics of Archaea and Bacteria, 125 .

Tebruegge, M., Pantazidou, A. Clifford, V. Gonis, G. Ritz, N. Connell, T. Curtis, N. 2011. The age-related risk of coexisting meningitis in children with urinary tract infection. PLoS One., 6, 49.

Teixeira, 2011. Manual of clinical microbiology. 10th ed. American Society for Microbiology; Washington, DC: 2011. 2630

Tello, A., Austin, B. Telfer, T.C. 2012. Selective pressure of antibiotic pollution on bacteria of importance to public health. Environ. Health Perspect, 120, 1100-1106.

Ullah, F.F., Malik, S.A. Ahmed, J. Ullah, F.F. Ayaz, M. Hussain, S. Khatoon, L. Shah, S.M. Ayaz, M. Hussain, S. Khatoon, L. 2012. Investigation of the Genetic Basis of Tetracycline Resistance in
Staphylococcus aureus from Pakistan. Trop. J. Pharm. Res., 11, 925-931.

Uma, A., and Ronald, B.S. 2016. Drug Resistance in Mycobacterium fortuitum isolated from gold fish, Carassius auratus. Int. J. Sci. Environ., 5, 44114417.

Valenzuela, A.S., Benomar, N. Abriouel, H. Cañamero, M.M. Gálvez, A. 2010. Isolation and identification of Enterococcus faecium from seafoods: Antimicrobial resistance and production of bacteriocin-like substances. Food Microbiol, 27, 955-961.

Vankerckhoven, V., Van Autgaerden, T. Vael, C. Lammens, C. Chapelle, S. Rossi, R. Jabes, D. Goossens, H. 2004. Development of a multiplex PCR for the detection of asaI, gelE, cylA, esp, and hyl genes in Enterococci and survey for virulence determinants among european hospital isolates of Enterococcus faecium. J. Clin. Microbiol, 42, 4473-4479.

Wilson, I.G., and McAfee, G.G. 2002. Vancomycin-resistant Enterococci in shellfish, unchlorinated waters, and chicken. Int. J. Food Microbiol, 79, 143-151.

\section{How to cite this article:}

Uma Arumugam, Nattan Stalin and Gnanadesika pandian Rebecca. 2017. Isolation, Molecular Identification and Antibiotic Resistance of Enterococcus faecalis from Diseased Tilapia. Int.J.Curr.Microbiol.App.Sci. 6(6): 136-146. doi: https://doi.org/10.20546/ijcmas.2017.606.016 